\title{
Charge Recombination Suppressed CdSeS/CdSe/ZnS QDSSC Design
}

\section{Yük Rekombinasyonu Baskılanmış CdSeS/CdSe/ZnS QDSSC Tasarımı}

\section{Erdem Elibol}

Department of Electric and Electronic Engineering, Düzce University, Düzce, Turkey.

\section{ABSTRACT}

The

he interest in quantum dot sensitized solar cells (QDSSC), which has theoretically proved to have up to $44 \%$ energy conversion efficiency in recent years, is growing rapidly. Although it has theoretically high efficiency value, PCE obtained in studies with QDSSCs is far from these values. This situation shows that there are many difficulties to be solved in QDSSC technology. One of the main challenges in QDSSC technology is irradiated load recombination occurring in QDSSC. For this reason, in this study, it is about using CdSeS QDs as an alternative to the most used CdS QDs in the literature in order to suppress the load recombination between $\mathrm{TiO}_{2}$ surface and electrolyte and QD surfaces. In the study, while CdS and CdSeS QDs were coated on the $\mathrm{TiO}_{2}$ surface with SILAR method, the previously synthesized CdSe QD was coated with chemical deep deposition method. Surfaces were last treated with ZnS QDs. An optimization study was carried out to determine the ideal number of CdSeS coatings for QDSSCs. As a result, the Jsc and Voc values for $\mathrm{TiO}_{2} / \mathrm{CdSeS}_{4} / \mathrm{CdSe}_{\mathrm{ZnS}}$ QDSSCs were $8.799 \mathrm{~mA} /$ $\mathrm{cm}^{2}$ and $0.795 \mathrm{~V}$, respectively, while the PCE value increased to $4.452 \%$.

\section{Key Words}

QDSSC, charge recombination;,CdSeS, CdSe.

\section{öz}

Son yıllarda teorik olarak \%44'e kadar enerji dönüşüm verimliliğine sahip olabileceği kanıtlanan Kuantum nokta duyarlı güneş hücrelerine (QDSSC) olan ilgi hızla artmaktadır. Teorik olarak yüksek olan verim değerine sahip olmasına karşın QDSSC'ler ile yapılan çalışmalarda elde edilen PCE bu değerlerden oldukça uzaktadır. Bu durum QDSSC teknolojisinde çözülmesi gereken birçok zorluk olduğunu göstermektedir. QDSSC teknolojisinde ki başlıca zorluklardan bir tanesi QDSSC'de meydana gelen ışınımsız yük rekombinasyonlarıdır. Bu sebeple bu çalışmada $\mathrm{TiO}_{2}$ yüzey ile elektrolit ve $\mathrm{QD}$ yüzeyleri arasında meydana gelen yük rekombinasyonlarını baskılayabilmek için $\mathrm{TiO}_{2}$ yüzeyinin literatürde en çok kullanılan CdS QD’lara alternatif olarak CdSeS QD'ların kullanılması üzerinedir. Yapılan çalışmada CdS ve CdSeS QD'ların $\mathrm{TiO}_{2}$ yüzeyine SILAR metoduyla kaplanırken, önceden sentezlenmiş olan CdSe QD kimyasal banyo birikimi metoduyla kaplanmıştır. Yüzeyler son olarak ZnS QD'lar ile tedavi edilmiştir. QDSSC'ler için en ideal CdSeS kaplama sayısını tespit edebilmek için optimizasyon çalışması yapılmıştır. Sonuç olarak $\mathrm{TiO}_{2} / \mathrm{CdSeS}_{4} / \mathrm{CdSe} /$ ZnS QDSSC'ler için Jsc ve Voc değerleri sırasıyla $8.799 \mathrm{~mA} / \mathrm{cm}^{2}$ ve $0.795 \mathrm{~V}$ iken PCE değeri \%4.452'e yükseltilmiştir.

\section{Anahtar Kelimeler}

QDSSC, yük rekombinasyonu, CdSeS, CdSe.

Article History: Received: Sep 16, 2020; Revised: Dec 7, 2020; Accepted: Feb 7, 2021; Available Online: Feb 7, 2021.

DOI: https://doi.org/10.15671/hjbc.795908

Correspondence to: E.Elibol, Department of Electric and Electronic Engineering, Düzce University, Düzce, Turkey.

E-Mail: erdemelibol@duzce.edu.tr 


\section{INTRODUCTION}

The he unique optical and electrical properties of quantum dots (QD) proven theoretically and experimentally make them superior to bulk semiconductor materials. QDs are under the influence of quantum confinement effect in all three dimensions, and this is one of the main reasons for this fundamental difference in the electrical properties of QDs [1]. QDs have adjustable absorbance and emission characteristics according to their sizes [2]. They have multiple excitons generation (MEG) potential $[3,4]$ narrow full with half maxımum (FWHM) [5], high photo-luminescence quantum yield (PLQY) [6]. In fact, QDs find application areas on a wide scale ranging from biological imaging [7] to LED technology [8], energy sector [9] and textile industry [10].

One of the usage areas of QDs is solar energy systems. Quantum dot sensitized solar cells (QDSSC) is one of the sub-categories of third generation solar panels that are studied alternatively to the first and second generation solar panels [11]. The power conversion efficiency (PCE) of the solar panels produced with Bulk semiconductor materials, especially Si-based materials, is limited to a maximum of 33.3\% with the Shockley-Queisser limit [12]. In contrast, solar panels designed with QDs have proven to be up to $44 \%$ theoretically due to the ability of QDs to produce MEG from a single photon [13]. This has recently increased interest in QDSSC. However, in the current literature, PCE of QDSSC remains low compared to other solar panels. There are many challenges that must be overcome and overcome to improve the performance of QDSSCs. One of these difficulties is non-radiative charge recombination, which consists of QD structure [14]. In order to suppress non-radiative charge recombination occurring in QDs, the surface ligands of the QDs are changed, or another QD in the form of shells is coated in the core QDs $[6,15]$. It has been observed that both of these methods give successful results. However, another basic charge recombination within the QDSSC structure takes place between the $\mathrm{TiO}_{2}$ surface and $\mathrm{QD}$ and the electrolyte. Coating $\mathrm{TiO}_{2}$ surfaces with $\mathrm{CdS}$ QDs is one of the most widely used methods to reduce or suppress this load recombination [16]. Another coating method used as an alternative is ZnS QDs [17]. Although both methods give successful results, the energy conversion efficiency of QDSSCs is still very low.

CdSe QDs are the most used QDs in QDSSC studies. Chen et al coated the $\mathrm{TiO}_{2}$ surface with CdSe QDs in dif- ferent sizes and hybrids of different sizes and designed QDSSCs. In their study, it was found that the hybrid use of two different sizes of CdSe QDs outperformed their individual use and increased PCE to $1.26 \%$ [18]. Lee and Lo reported that the conductivity band edges and energy band spacing of CdS QDs are higher than CdSe QDs and that the CdS/CdSe QDSSC design is more efficient than CdS QDSSC and CdSe QDSSC. So much so that in the CdS/CdSe QDSSC study that they used Au collecting electrodes, PCE increased up to 4.22\% [19]. Yu et al coated the surface of CdSe QDs with CdS QDs in order to reduce charge recombination occurring on the surface of CdSe QDs. As a result of their work, the PCE of CdSe QDSSC increased to 4.21\% [20]. Liu and ark zinc made extra $\mathrm{ZnS} / \mathrm{SiO}_{2}$ coating as surface passivation in $\mathrm{CdS} / \mathrm{CdSe}$ QDSSCs, which they built on titanium mixed metal oxides base. In the study, it was determined that the $\mathrm{ZnS} / \mathrm{SiO}_{2}$ layer had a success in suppressing charge recombination and increased the PCE of QDSSC to 4.91\% [21] (QD.

In this study, CdSeS QDs were used as an alternative to the most preferred CdS QDs in the literature to suppress charge recombination between $\mathrm{TiO}_{2}$ surfaces and CdSe QD and electrolyte surfaces. In the study, MPA coated CdSe QDs were synthesized, and CdS and CdSeS QDs coated on $\mathrm{TiO}_{2}$ surface were coated with SILAR method. Coating of CdSe QDs on $\mathrm{TiO}_{2} / \mathrm{CdS}$ (CdSeS) surfaces was carried out by chemical bath deposition (CBD) method. Absorbent, emission and XRD measurements were performed to show that the synthesized CdSe QDs are compatible with the literature. I-V measurements were made for the designed QDSSCs and an optimization study was carried out on how many cycles the CdSeS QDs should be covered.

\section{MATERIALS and METHODS}

\section{Preparation of $\mathrm{TiO}_{2}$ surface}

Before coating the $\mathrm{TiO}_{2}$ surfaces to the FTO surface, the FTO surfaces need to be cleaned. For this reason, FTO surfaces washed with detergent and distilled water are then washed in an ultrasonic bath with $\mathrm{HCl}$ and ethanol for 15 min respectively, and dried and stored with nitrogen gas $\left(\mathrm{N}_{2}\right)$. Then, the conductive surface is determined and $\mathrm{TiO}_{2}$ coating process is started. In this study, $\mathrm{TiO}_{2}$ surface; Transparent, active and reflective surfaces were coated on 3 layers in FTO surface. Surfaces were covered with doctor blade method and sintering was performed at $450^{\circ} \mathrm{C}$ for 30 min after coating each layer. 


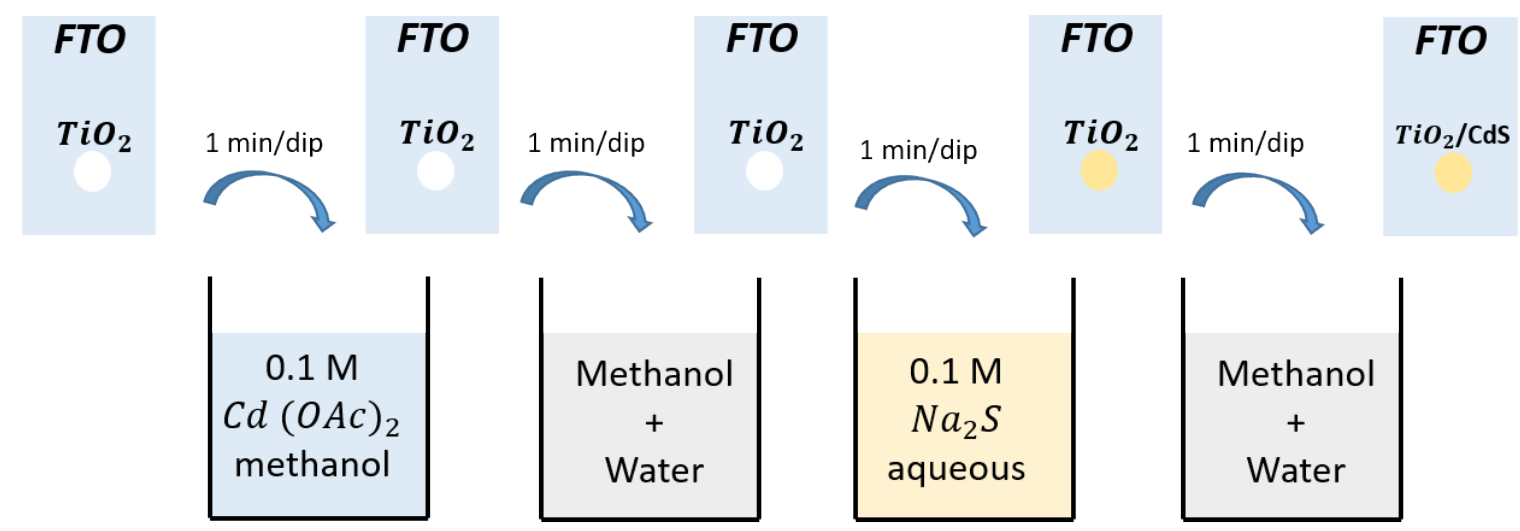

Figure 1. Schematic representation of the steps applied in the coating of CdS QDs on $\mathrm{TiO}_{2}$ surfaces by SILAR method.

After the surface layer had cooled down, the other layer was covered with the Doctor Blade method and a similar sintering process was followed.

Following the coating of $\mathrm{FTO} / \mathrm{TiO}_{2}$ surfaces, $\mathrm{TiCl}_{4}$ treatment was applied [22]. It was previously experimentally proven that $\mathrm{TiCl}_{4}$ treatment is an effective treatment of electron transfer of QDs with $\mathrm{TiO}_{2}$ surface, $\mathrm{TiCl}_{4}$ treat ment has been shown to increase the adhesion rate of QDs to the $\mathrm{TiO}_{2}$ surface [22]

\section{Coating of CdS QDs on $\mathrm{TiO}_{2}$ surface}

CdS QDs are one of the most commonly used surface layers to suppress load recombination occurring on the $\mathrm{TiO}_{2}$ surface. In this study, CdS QD coating was applied to compare CdSeS QDs. Successive ionic layer adsorption and reaction (SILAR) method was used to coat the CdS QDs on the $\mathrm{TiO}_{2}$ surface [23]. For CdS QD coating, $0.1 \mathrm{M} \mathrm{Cd}(\mathrm{OAc})_{2}$ was dissolved in methanol and used for $\mathrm{Cd}^{2+}$ load solution while for the $\mathrm{S}^{2-}$ load solution, $0.1 \mathrm{M}$
$\mathrm{Na}_{2} \mathrm{~S}$ was dissolved in methanol/pure water mixture ( $\mathrm{v}: \mathrm{v}$, 1:1). After the preparation of the $\mathrm{Cd}$ and $\mathrm{S}$ precursors, the $\mathrm{FTO} / \mathrm{TiO}_{2}$ surface desired to be coated with $\mathrm{CdS}$ QD was immersed in the prepared $\mathrm{Cd}^{2+}$ and $\mathrm{S}^{2-}$ solutions, respectively. Firstly, the surface immersed in $\mathrm{Cd}^{2+}$ solution for $1 \mathrm{~min}$ after then it washed with methanol/ ultra-pure water mixture and immersed in $\mathrm{S}^{2}$ - solution for and other $1 \mathrm{~min}$. At the end the surface last time washed with methanol/ultra-pure water mixture and 1 SILAR cycle of CdS QD was finished. These SILAR method steps are shown in Figure 1. The 4 cycles coating recommended in the literature was used to coat the cdS QDs.

\section{Coating of CdSeS QDs on $\mathrm{TiO}_{2}$ surface}

Se powder was added to the $\mathrm{Na}_{2} \mathrm{~S}$ solution used in the SILAR method of CdS QDs to coat the CdSeS QDs on the $\mathrm{TiO}_{2}$ surface. While adding Se amount, Se:S ratio was set as 1:4. The $\mathrm{Cd}^{2+}$ precursor solution was adjusted to be the same as the previous one. After the precursor

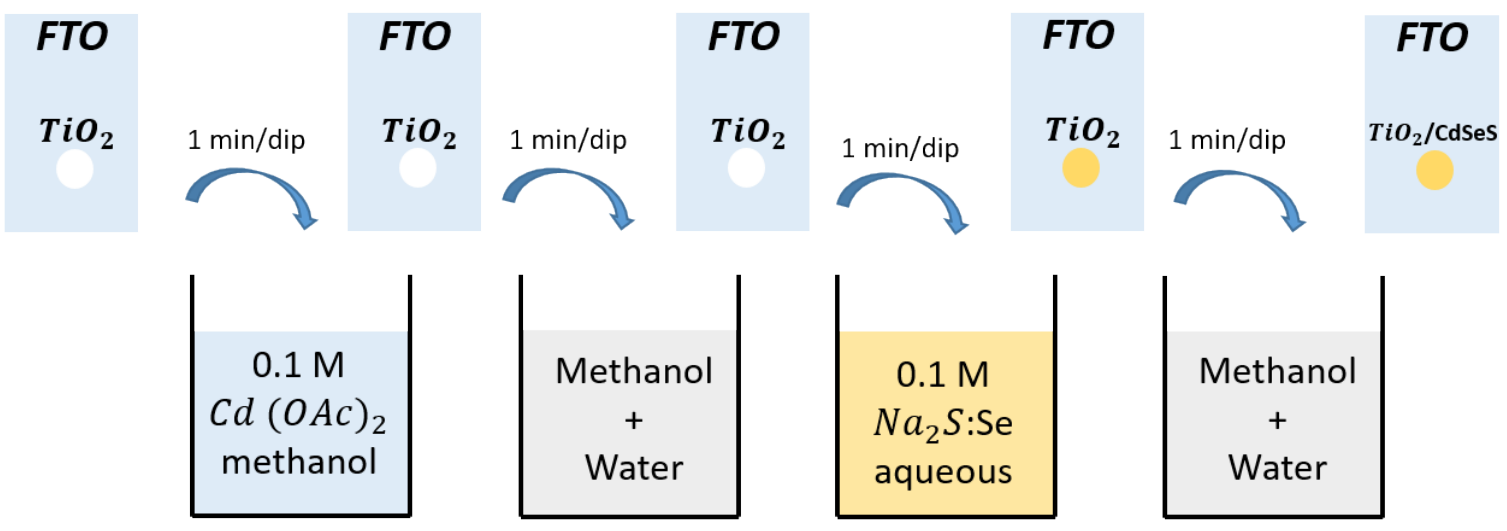

Figure 2. Schematic representation of the steps applied in the coating of CdSeS QDs on $\mathrm{TiO}_{2}$ surfaces by SILAR method. 
solutions were ready, $\mathrm{TiO}_{2}$ was first immersed in the Cd precursor $1 \mathrm{~min}$, respectively, and at the end of this period it was washed with the methanol/ultra-pure water mixture. Then, the surface immersed in Se:S precursor solution for $1 \mathrm{~min}$ and then it was washed in the methanol / ultra-pure water mixture and a SILAR cycle was completed. The SILAR method applied for coating the CdSeS QDs on the $\mathrm{TiO}_{2}$ surface was tried to be optimized in this study. For this reason, CdSeS QD coating process was performed between 1-7 cycles. One SILAR cycle of coating CdSeS is schematicly shown at Figure 2 .

\section{Synthesis of CdSe QDs and coating on surface}

In this study, CdSe QDs were pre-synthesized and coated on the surfaces. CdSe QD synthesis was performed by the method proposed by Chen et al. Partial changes were made in the method [24]. In order to synthesize CdSe QDs, first prepare sodium selenosulphate solution, mix $1 \mathrm{~g}$ sodium sulphite, $0.1 \mathrm{~g}$ selenium powder and 66 $\mathrm{ml}$ ultra-distilled water. The mixture was kept in an inert environment at $80^{\circ} \mathrm{C}$ for 4 hours and stored at room temperature. As a $\mathrm{Cd}$ precursor, $0.128 \mathrm{~g}$ of $\mathrm{Cd}(\mathrm{Ac})_{2}$ $2 \mathrm{H}_{2} \mathrm{O}$ and $100.4 \mu \mathrm{L}$ of 3-MPA were mixed in $98 \mathrm{~mL}$ of ultrapure water. Then the $\mathrm{pH}$ of the mixture was adjusted to 10 with $1 \mathrm{M} \mathrm{NaOH}$ and the mixture was taken to the inert medium and left in the mixture. When both precursors were ready, sodium seleosulphate was injected into the Cd precursor and CdSe QDs were grown at 100 ${ }^{\circ} \mathrm{C}$. Then the temperature of the mixture was lowered to room temperature. To prepare CdSe QDs for use, they were first washed with methanol, centrifuged and redissolved with ultrapure water. Finally, adjust the $\mathrm{pH}$ to 10 with $0.2 \mathrm{M} \mathrm{NaOH}$ and made it ready for use.

Deep coating method was used to coat previously synthesized CdSe QDs on $\mathrm{TiO}_{2}, \mathrm{TiO}_{2} / \mathrm{CdS}$ and $\mathrm{TiO}_{2} / \mathrm{CdSeS}$ surfaces. For this reason, the surfaces were immersed in CdSe $Q D$ aqueous solutions and kept in solution for 12 hours.

\section{Zns Coating on surface}

It has been previously reported that coating the ZnS QDs as the passivation surface that prompts CdSe QDs to be coated on the surfaces gives positive results in the QDSSC performance. ZnS QDs act as a barrier layer, both helping to passivation the surfaces and effective in suppressing charge recombination [25]. For this reason, ZnS QDs were used as a barrier layer in this study. ZnS QD coating process was carried out by SILAR method and $0.1 \mathrm{M} \mathrm{Zn}\left(\mathrm{NO}_{3}\right)_{2}$ and $0.1 \mathrm{M} \mathrm{Na}_{2} \mathrm{~S}$ solutions were prepared in the ultra-pure water as $\mathrm{Zn}^{2+}$ and $\mathrm{S}^{2-}$ precursors, respectively [26]. The $Q D$ coated surfaces are immersed in $\mathrm{Zn}^{2+}$, ultrapure water and $\mathrm{S}^{2-}$ precursors for 1 min respectively and 1 SILAR cycle was completed by washing with ultrapure water again. In the study, 2 SILAR loops were applied to the surfaces.

\section{Preparation of Counter electrode and electrolyte}

In the study, Pt was used as the collecting electrode, and the coating of Pt on FTO surfaces was performed using the electrochemical deposition technique [27]. Iodine / iodide redox pair was used as electrolyte.

\section{Characterization}

In the study, absorbance and emission measurements were made for the CdSe QDs that were previously synthesized. In order to determine the crystal structure, X-Ray Diffraction (XRD) analysis was performed. In addition, 5 repeated measurements were made with the designed solar cells and I-V characterizations were removed.

\section{RESULTS and DISCUSSION \\ Optical and Structured Analyses of pre-synthesised CdSe QD}

In the study, firstly, absorbance and emission studies were performed for the previously synthesized CdSe QDs. The absorbance characterization of CdSe QDs was performed using the UV-1800 Shimadzu UV-vis Spectrometer device. Absorbance spectrum scanning was performed on a scale of 300-700 $\mathrm{nm}$ and is shown in Figure 3. The primary peak wavelength for CdSe QDs was measured as $474 \mathrm{~nm}$. Equation 1 [28] was used to determine the size of CdSe QDs and it was found that the size of CdSe QDs synthesized and used in solar cell design were $2.08 \mathrm{~nm}$. The absorbance characterization for the synthesized CdSe QDs is compatible with studies in the literature $[29,30]$.

Emission characterization studies for synthesized CdSe QDs were carried out using the Model TM-2/2005 Lifetime Spectrofluorometer device. While $380 \mathrm{~nm}$ was used in the excitation of CdSe QDs, 300-700 nm was preferred as the measurement range. The emission results obtained are shown in Figure 3. The emission maximum peak for CdSe QDs was determined to be 493 $\mathrm{nm}$. The emission graph has been normalized to better interpret the results. When Figure 3 is examined, it 


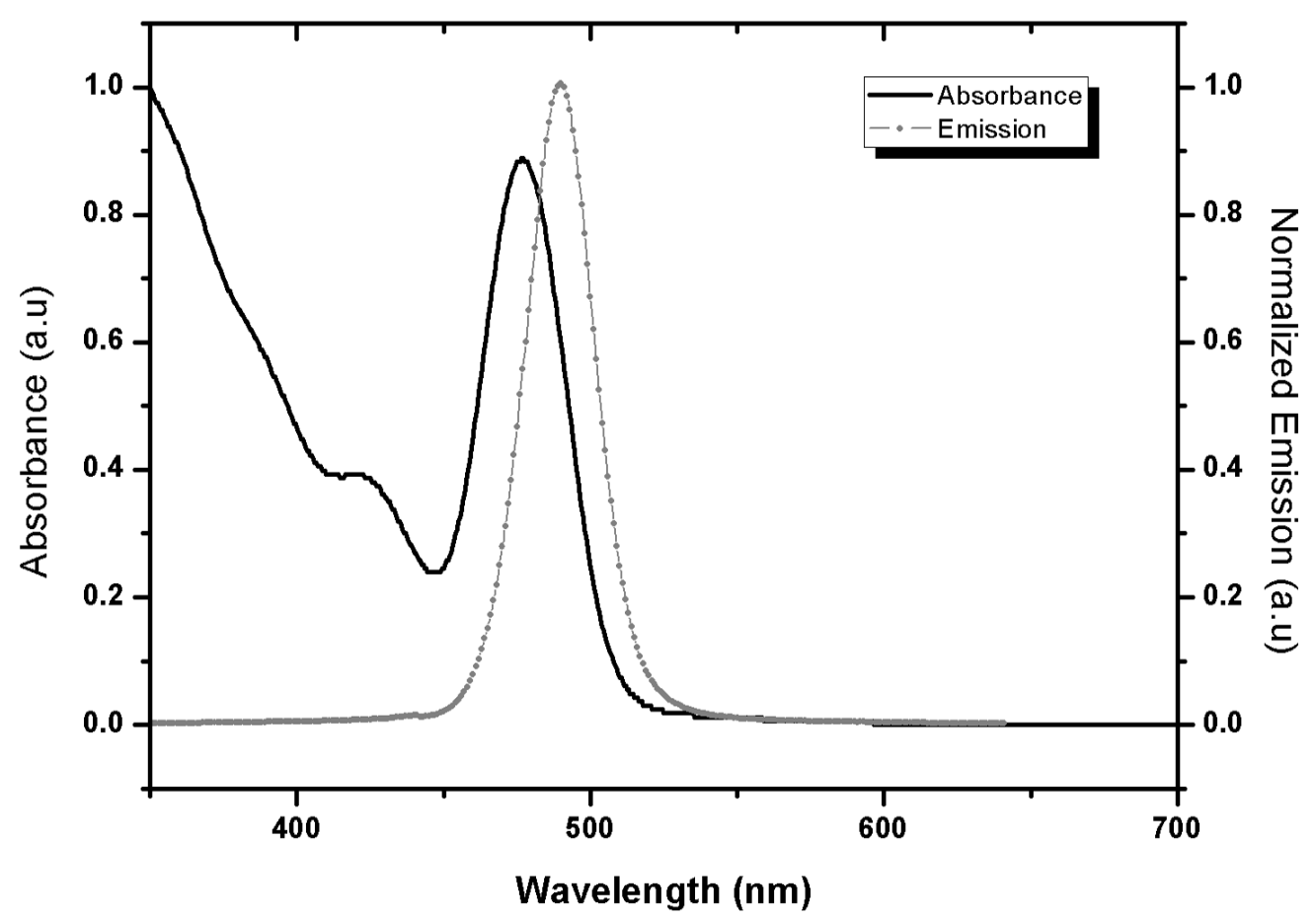

Figure 3. Absorbance and emission characterization of pre-Synthesised CdSe QDs.

$\operatorname{CdSe}(\mathrm{nm})=\left(1.6112^{*} 10^{-9}\right) * \lambda^{4}-\left(2.6575^{*} 10^{-6}\right) * \lambda^{3}+\left(1.6242^{*} 10^{-3}\right) * \lambda^{2}-(0.4277) * \lambda+41.57$

has been determined that there is a $19 \mathrm{~nm}$ stock shift in absorbance and emission peaks, which is consistent with the results obtained in the literature. In the analysis made with Origin Pro8 for the emission peak, the FWHM value was found to be $32 \mathrm{~nm}$, in which case the size distribution in the solution is a clear indication that it can be kept under control.

In order to detect the crystal structure for presynthesized CdSe QDs, XRD analyzes were performed with the RIGAKU smartlab device and the results obtained are normalized and shown in Figure 4. The diffraction peaks for CdSe QDs were detected at 26.3, 42.2 and 48.9 respectively. When the XRD pattern was examined, it was found that the peaks (111), (220) and (311) represent the cubic zinc blended crystal door and that the synthesized CdSe QDs are compatible with the crystal structures defined in the literature [24]. This is important to determine that the synthesized CdSe QDs can be used in QDSSC designs and have the desired crystal properties.

\section{Characterization of QDSSCs}

In order to be able to perform J-V characterization operations in QDSSC designs and to show that the results obtained are reproducible, 5 of each type of QDSSC were designed. The average values of the results obtained for these 5 replicate QDSSCs, all parameters of which were equal, were shared in the study. The results were given step by step in order to categorize the J-V characterization studies.

In the first stage, CdSe, CdS/CdSe and CdSeS/CdSe QDs were coated on the $\mathrm{TiO}_{2}$ surface, respectively. 5 cycles of SILAR cycles were repeated in coating the CdS QDs. In the closing of CdSeS QDs, the results of which were given at this stage, were coated with 2 cycles of SILAR. In order to provide a standard for all designed QDSSCS, CdSe QDs are coated with deep coating method for 12 hours. In these 3 different QDSSC designs, ZnS QD barrier surface was not used. While the J-V characteristic curves obtained are shown in Figure 5, detailed parameter results for QDSSCs are given in Table 1. 


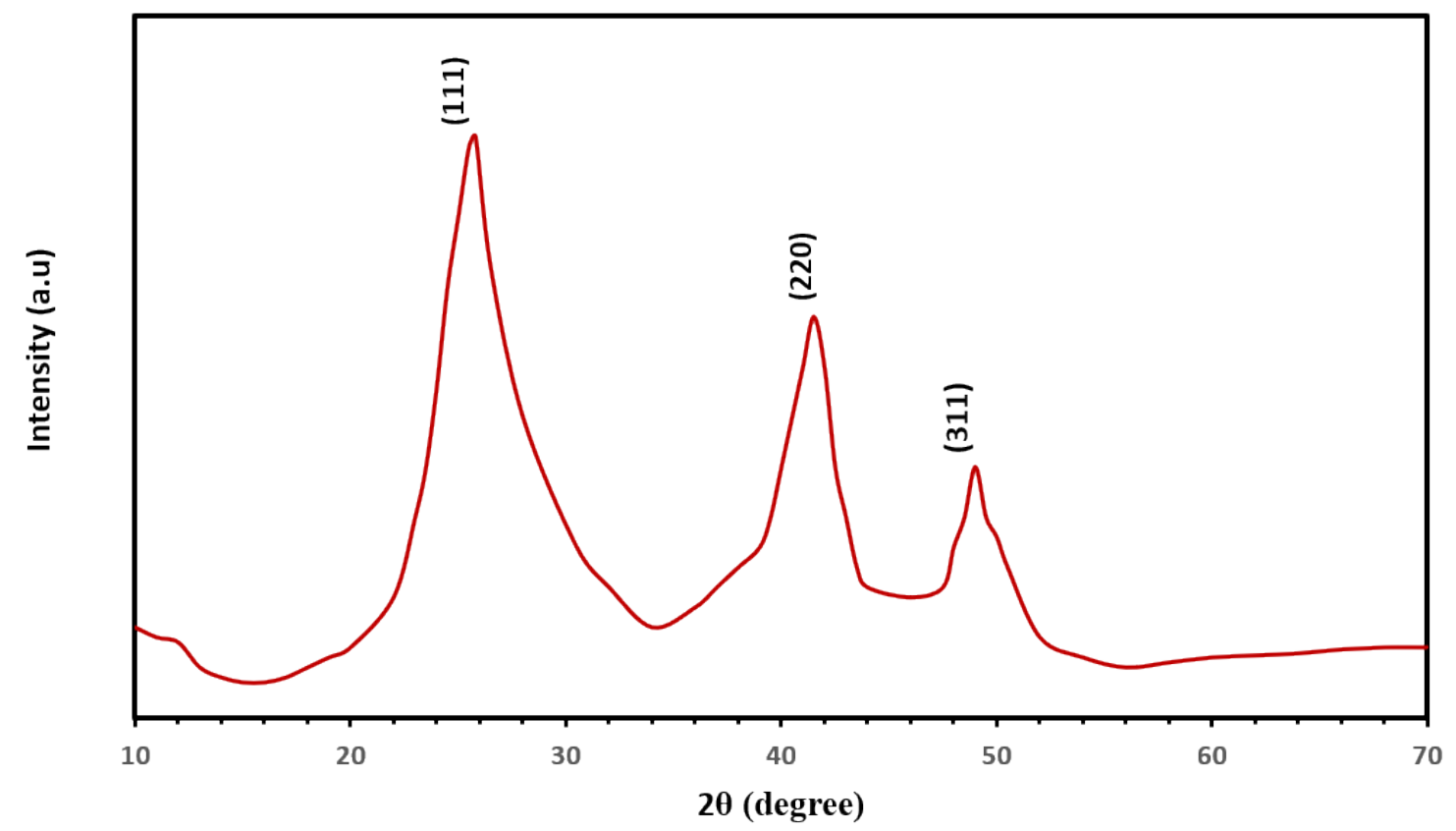

Figure 4. XRD analyses of pre-synthesised CdSe QDs.

When Figure 5 and Table 1 are examined in detail, it is seen that the PCE values of the QDSSCs with only CdSe QDs on $\mathrm{TiO}_{2}$ surface remain at $0.539 \%$. In their study, Pawar et al calculated the PCE of $\mathrm{TiO}_{2} / \mathrm{CdSe}$ QDSSC as $1.11 \%$. In this study, they used $\mathrm{TiO}_{2}$ nanorods surface and showed that the use of $\mathrm{TiO}_{2}$ in nanorods form increased performance. In this study, $\mathrm{TiO}_{2}$ surfaces were used in 3 different layers in a porous way and lower results were obtained from Pawar et al [26]. In contrast, in CdS/CdSe QDSSC designs, PCE increased up to $2.162 \%$. This shows that CdS QDs are effective in load recombination and cause QDSSC to increase about 4 times in PCE value. Studies similar to this increase of CdS QD layer in PCE are also found. Also in their study, Pawar et al found PCE as $1.53 \%$ for CdS/CdSe QDSSC. In the study of Pawar et al, Pt was used as the collecting electrode, while sulphate/polysulfide was used as the electrolyte [26]. It is known that Pt and sulphate/polysulfide pair cause decreases in Jsc value of QDSSC. It is known that $\mathrm{Pt}$ and iodine/iodine redox couple are more compatible and increase Voc value [31]. Lee et al reported PCE as $2.86 \%$ for CdS/CdSe QDSSCs. Unlike this study, Lee et al performed coating of CdSe QDs with the SILAR method [23]. In this study, the reason why PCE was lower than the study by Lee et al is thought to be due to using presynthesized CdSe QDs with SILAR method. In the SILAR method, the adhesion rate of QDs on the surface is higher.
CdSeS QDs, which were used as an alternative to CdS QDs specifically for this study, were coated on the $\mathrm{TiO}_{2}$ surface as 2 SILAR cycles at this stage. Jsc, Voc and PCE values for CdSeS/CdSe QDSSCs were $7.486 \mathrm{~mA} / \mathrm{cm}^{2}$, $0.783 \mathrm{~V}$ and $3.366 \%$, respectively. Coating of $\mathrm{TiO}_{2}$ surface with CdSeS QDs increased PCE 1.55 times compared to CdS QDs. An increase in both Jsc value and Voc value of CdSe QDSSC was observed. The main reason for the increase of these parameter values is thought to be due to the fact that CdSeS QDs have a wider band gap than CdS QDs and have more suitable band edge levels for electron transfer with $\mathrm{TiO}_{2}$. Yang and Zong showed in their study that CdTe/CdSeS QDSSCs are effective in electron transfer because CdSeS QDs have a wider bandwidth than CdTe QDs [32]. Although Yang and Zong used the CdSeS QDs to inactivate the CdTe QDs, rather than to prevent load recombination occurring on the $\mathrm{TiO}_{2}$ surface, the results are consistent.

In the second stage, ZnS coating was made in the form of 2 SILAR cycles in order to examine the effects of ZnS barrier surface on PCE in QDSSC design. In this way, 3 different QDSSCs are designed as CdSe/ZnS, CdS/CdSe/ $\mathrm{ZnS}$ and $\mathrm{CdSeS} / \mathrm{CdSe} / \mathrm{ZnS}$. As stated in the previous section, the parameter values are exactly the same with 5 replicates from each QDSSC. In these QDSSC designs, 3 layers of $\mathrm{TiO}_{2}$ surface were used and $\mathrm{TiCl}_{4}$ treatment 


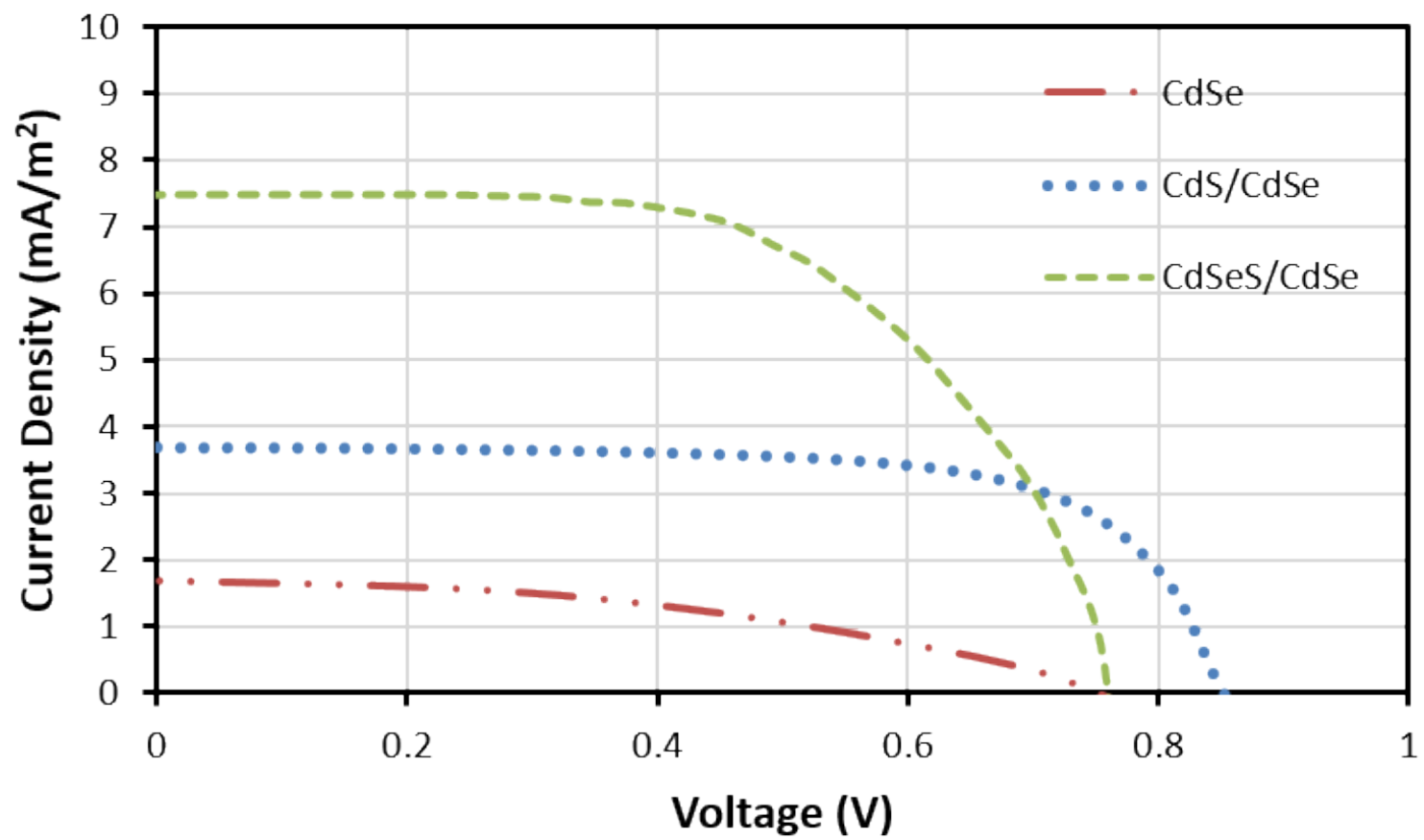

Figure 5. J-V characterization of 3 different CdSe QDSSCs.

was not applied to $\mathrm{TiO}_{2}$ surfaces. Pt was used as each QDSSC collector electrode, and iodine/iodide redox pair was used as electrolyte. The characteristic curve obtained as a result of J-V measurements for these QDSSCS is shown in Figure 6. As can be seen in Figure 6, CdS/ CdSe/ZnS QDSSCs have the highest Voc value, whereas Jsc values remain low to $\mathrm{CdSeS/CdSe/ZnS} \mathrm{QDSSCs.} \mathrm{For}$ CdSe/ZnS QDSSCs, both Voc and Isc values remained low compared to the other two QDSSC types. Detailed parameter results obtained as a result of J-V measurements are shown in Table 2.
Using ZnS barrier layer compared to CdSe QDSSCs with PCE value $0.539 \%$ increased PCE value to $0.643 \%$. It has been previously reported that the coating of $\mathrm{ZnS}$ until it reaches a certain thickness value due to the wide bandwidths they have compared to CdSe QDs, increases the PCE value of the QDSSC [33]. In this study, the ZnS barrier layer caused an increase in the performance of QDSSC in line with the studies in the literature [34]. As can be seen in Table 2, PCE value for CdSeS/CdSe/ZnS QDSCCs increased up to $3.637 \%$. This increased the PCE of the CdSeS/CdSe QDSSC of the ZnS layer by $8 \%$. The main reason for the increase in PCE of CdSeS/CdSe/ZnS QDSSCs is the increase in Jsc value. So much so that the

Table 1. J-V characterization parameters of 3 different CdSe QDSSCs.

\begin{tabular}{ccccccc}
\hline & $\mathrm{Jsc}\left(\mathrm{mA} / \mathrm{m}^{2}\right)$ & $\operatorname{Voc}(\mathrm{V})$ & $J \max \left(\mathrm{mA} / \mathrm{m}^{2}\right)$ & $V \max (\mathrm{V})$ & $\mathrm{FF}(\%)$ & $\mathrm{PCE}(\%)$ \\
\hline CdSe & 1.673 & 0.750 & 1.189 & 0.454 & 42.979 & $0.539 \pm 0.081$ \\
\hline $\mathrm{CdS} / \mathrm{CdSe}$ & 3.690 & 0.849 & 3.159 & 0.684 & 68.999 & $2.162 \pm 0.101$ \\
\hline CdSeS/CdSe & 7.486 & 0.783 & 6.461 & 0.521 & 57.428 & $3.366 \pm 0.123$ \\
\hline
\end{tabular}




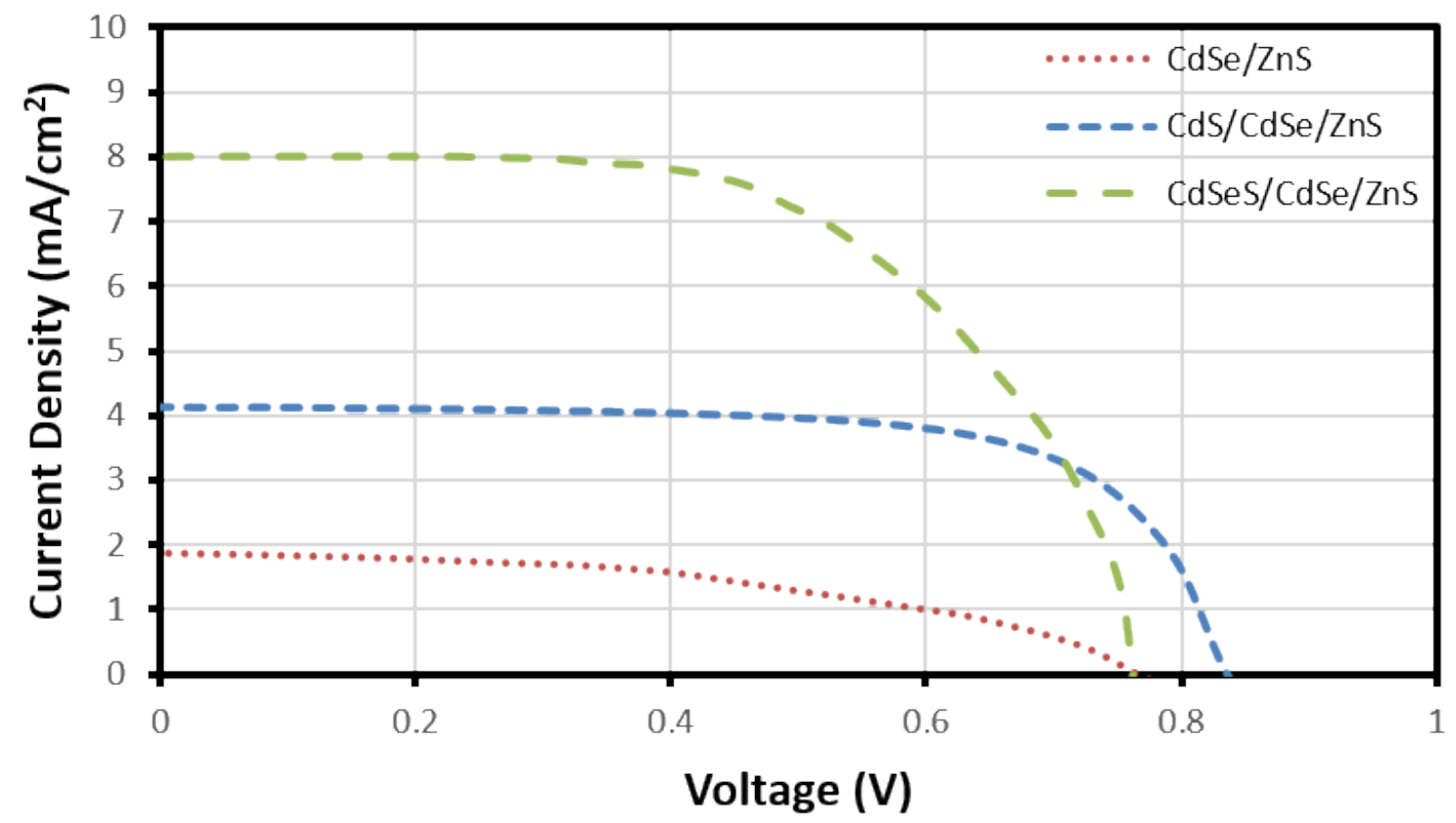

Figure 6. J-V characterization of ZnS barrier layer coated 3 different CdSe QDSSCs.

Jsc value, which is $7.486 \mathrm{~mA} / \mathrm{cm}^{2}$ without the $\mathrm{ZnS}$ layer, has increased up to $8.006 \mathrm{~mA} / \mathrm{cm}^{2}$ with the ZnS layer. This indicates that the $\mathrm{ZnS}$ layer with broadband spacing causes an increase in the contour electron transfer between the layers of the QDSSC.

In the first two stages, it was determined that CdSeS QDs can be used to suppress charge recombination of CdSe QDSSCs, and ZnS barrier layer has positive contributions for electron transfer. 3. As a step, optimization studies of SILAR cycle number of CdSeS QDs used in this study were performed. For this reason, $\mathrm{TiO}_{2}$ surfaces prepared in 3 layers and treated with $\mathrm{TiCl}_{4}$ were coated with CdSeS QDs in 1 to 7 SILAR cycles and J-V characterizations of the obtained QDSSCs were examined. At this stage, 5 repetitions were also worked for the QDSSCS designed. J-V characteristic curves obtained at the end of the study are shown in Figure 7. Similarly, detailed parameter values are given in Table 3.
In the measurements made, a significant increase was observed in the PCE and Jsc values of the CdSeS SILAR cycle number until 4 cycles. For $\mathrm{CdSeS/CdSe/ZnS}$ QDSSCs created with 1 SILAR cycle, while Jsc and PCE were $7.831 \mathrm{~mA} / \mathrm{cm}^{2}$ and $3.308 \%$ respectively, Jsc and PCE increased to $8.799 \mathrm{~mA} / \mathrm{cm}^{2}$ and $4.452 \%$, respectively, with 4 SILAR cycle. It can be mentioned that CdSeS QDs coated with 4 SILAR cycles basically suppress charge recombination with the redox pair and electron transfer is proportionally increased. The fact that load recombination was suppressed naturally increased JSC and PCE. However, with the increasing number of SILAR cycles, the performance of QDSSC decreased. In fact, JsC, Voc and PCE values of CdSeS/CdSe/ZnS QDSSCs created with 6 SILAR cycles decreased by $8.126 \mathrm{~mA} / \mathrm{cm}^{2}$, $0.702 \mathrm{~V}$ and $3.576 \%$ respectively. It was observed that the increase in the amount of CdSeS QDs on the surface started to prevent load transfer after a certain point, causing a decrease in the performance of QDSSC.

Table 2. J-V parameters of ZnS barrier layer coated QDSSC.

\begin{tabular}{ccccccc}
\hline & $\mathrm{Jsc}\left(\mathrm{mA} / \mathrm{m}^{2}\right)$ & $\operatorname{Voc}(\mathrm{V})$ & $\mathrm{Jmax}\left(\mathrm{mA} / \mathrm{m}^{2}\right)$ & $\operatorname{Vmax}(\mathrm{V})$ & $\mathrm{FF}(\%)$ & $\mathrm{PCE}(\%)$ \\
\hline $\mathrm{CdSe} /$ ZnS & 1.857 & 0.765 & 1.390 & 0.463 & 45.248 & $0.643 \pm 0.077$ \\
\hline $\mathrm{CdS} / \mathrm{CdSe} /$ ZnS & 4.128 & 0.832 & 3.534 & 0.671 & 68.999 & $2.371 \pm 0.142$ \\
\hline $\mathrm{CdSeS} / \mathrm{CdSe} /$ ZnS & 8.006 & 0.785 & 6.980 & 0.521 & 57.875 & $3.637 \pm 0.181$ \\
\hline
\end{tabular}




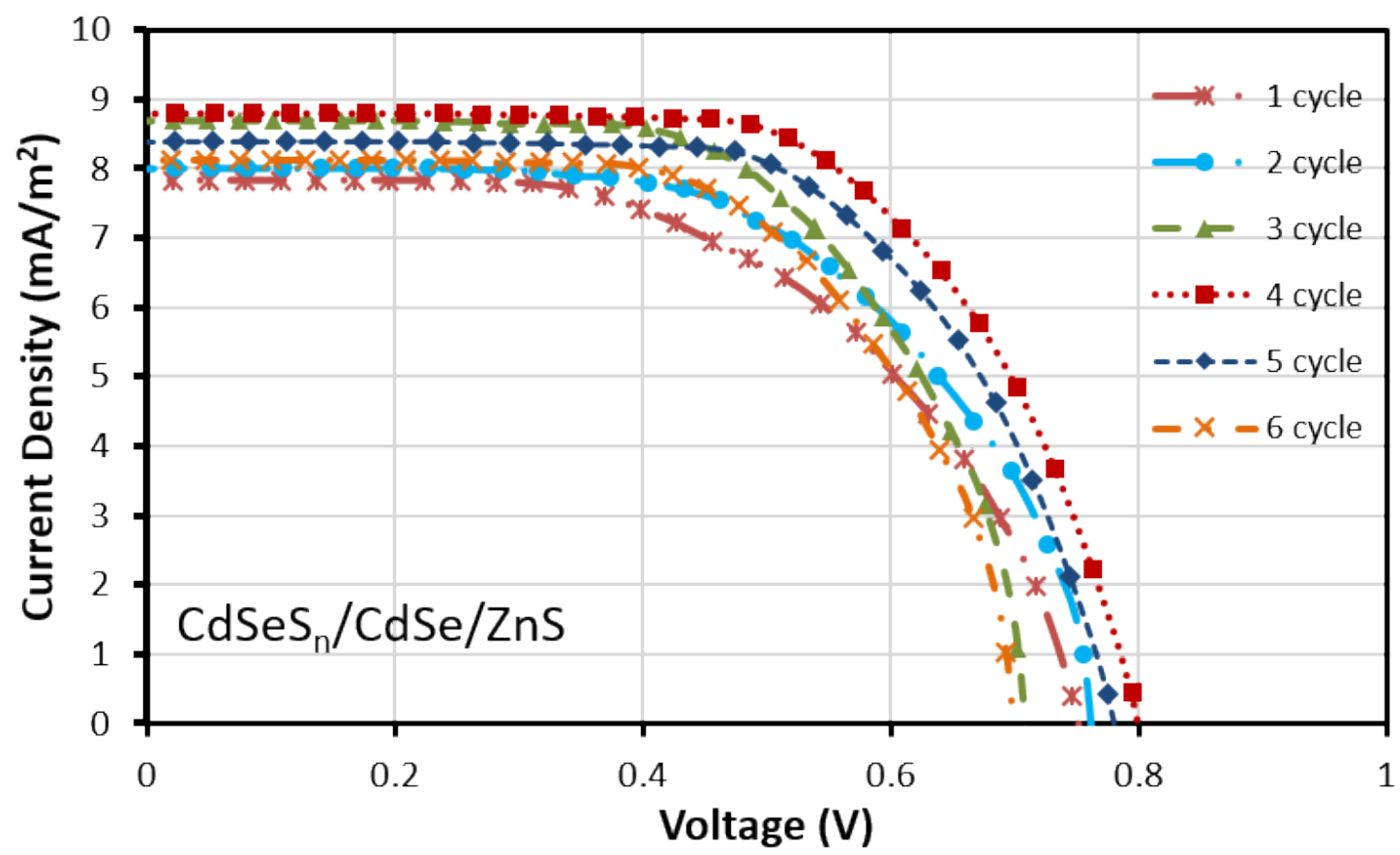

Figure 7. J-V characterization of QDSCCs depend on SILAR cycles of CdSeS QDs.

In this study, it was found that CdSeS QDs were used to coat $\mathrm{TiO}_{2}$ surface with SILAR method and to suppress load recombination as an alternative to CdS QDs, and CdSeS QDs achieved higher Jsc values. It is believed that the band edges of CdSeS QDs are more compatible with CdSe QDs and partially easy to electron transfer. In the optimization study, it was determined that coating with 4 SILAR cycles helps to reach the highest PCE value in CdSeS QDs coating with SILAR method.

\section{Conclusion}

In the present study, the use of CdSeS QDs proposed as an alternative to the most used CdS QDs in the literatu- re was tested to suppress load recombination occurring in CdSe QDSSCs. The results obtained have been found to cause reductions in load recombination due to the wide bandwidths of CdSeS QDs and the band edges that are more compatible with CdSe QDs. In the study, it was found that the coating of CdSeS QDs on $\mathrm{TiO}_{2}$ surface with 4 SILAR cycles provides the highest Jsc and PCE values for CdSeS/CdSe/ZnS QDSSCs. In fact, the highest PCE value obtained during the study was determined as 4.452\%. The study showed that CdSeS QDs are suitable for suppressing load recombination

Table 3. J-V characteristic parameters of QDSSCS depend on SILAR cycle of CdSeS QD.

\begin{tabular}{ccccccc}
\hline $\begin{array}{c}\text { Number the } \\
\begin{array}{c}\text { SILAR cycles of } \\
\text { CdSeSn }\end{array}\end{array}$ & Jsc $\left(\mathrm{mA} / \mathrm{m}^{2}\right)$ & Voc $(\mathrm{V})$ & $\mathrm{Jmax}(\mathrm{mA} / \mathrm{m} 2)$ & Vmax $(\mathrm{V})$ & FF (\%) & PCE (\%) \\
\hline 1 Cycle & 7.831 & 0.747 & 6.423 & 0.515 & 56.551 & $3.308 \pm 0.157$ \\
\hline 2 Cycle & 8.006 & 0.785 & 6.980 & 0.521 & 57.875 & $3.637 \pm 0.148$ \\
\hline 3 Cycle & 8.687 & 0.713 & 7.568 & 0.512 & 62.556 & $3.874 \pm 0.145$ \\
\hline 4 Cycle & 8.799 & 0.795 & 8.125 & 0.548 & 63.666 & $4.452 \pm 0.156$ \\
\hline 5 Cycle & 8.389 & 0.775 & 7.746 & 0.534 & 63.666 & $4.139 \pm 0.152$ \\
\hline 6 Cycle & 8.126 & 0.702 & 7.079 & 0.505 & 0.063 & $3.576 \pm 0.151$ \\
\hline
\end{tabular}




\section{References}

1. T. Takagahara, K. Takeda, Theory of the quantum confinement effect on excitons in quantum dots of indirectgap materials, Phys. Rev. B., 46 (1992) 15578-15581.

2. G. Nootz, L.A. Padilha, L. Levina, V. Sukhovatkin, S. Webster, L. Brzozowski, E.H. Sargent, D.J. Hagan, E.W. Van Stryland, Size dependence of carrier dynamics and carrier multiplication in PbS quantum dots, Phys. Rev. B - Condens. Matter Mater. Phys., 83 (2011) 155302

3. M.C. Beard, Multiple exciton generation in semiconductor quantum dots, J. Phys. Chem. Lett., 2 (2011) 1282-1288.

4. M.C. Beard, A.G. Midgett, M.C. Hanna, J.M. Luther, B.K. Hughes, A.J. Nozik, Comparing multiple exciton generation in quantum dots to impact ionization in bulk semiconductors: Implications for enhancement of solar energy conversion, Nano Lett., 10 (2010) 3019-3027.

5. P. Ramasamy, N. Kim, Y.S. Kang, O. Ramirez, J.S. Lee, Tunable, bright, and narrow-band luminescence from colloidal indium phosphide quantum dots, Chem. Mater., 29 (2017) 6893-6899.

6. M. Greben, A. Fucikova, J. Valenta, Photoluminescence quantum yield of $\mathrm{PbS}$ nanocrystals in colloidal suspensions J. Appl. Phys., 117 (2015) 144306.

7. V. Biju, S. Mundayoor, R. V. Omkumar, A. Anas, M. Ishikawa, Bioconjugated quantum dots for cancer research: Present status, prospects and remaining issues, Biotechnol. Adv., 28 (2010) 199-213.

8. F. Zhang, S. Wang, L. Wang, Q. Lin, H. Shen, W. Cao, C. Yang H. Wang, L. Yu, Z. Du, J. Xue, L.S. Li, Super color purity green quantum dot light-emitting diodes fabricated by using CdSe/ CdS nanoplatelets, Nanoscale, 8 (2016) 12182-12188.

9. E. Elibol, Effects of different counter electrodes on performance of CdSeTe alloy QDSSC, Sol. Energy., 197 (2020) 519-526.

10. R. Li, J. Che, H. Zhang, J. He, A. Bahi, F. Ko, Study on synthesis of $\mathrm{ZnO}$ nanorods and its UV-blocking properties on cotton fabrics coated with the $\mathrm{ZnO}$ quantum dot, J. Nanoparticle Res., 16 (2014) 2581.

11. A.M. Smith, S. Nie, Next-generation quantum dots., Nat. Biotechnol., 27 (2009) 732-733.

12. W. Shockley, H.J. Queisser, Detailed balance limit of efficiency of p-n junction solar cells, J. Appl. Phys., 32 (1961) 510-519.

13. E. Elibol, N. Tutkun, Improving CdTe QDSSC's performance by Cannula synthesis method of CdTe QD, Mater. Sci. Semicond. Process., 93 (2019) 304-316.

14. C.H. Wang, T. Te Chen, Y.F. Chen, M.L. Ho, C.W. Lai, P.T. Chou, Recombination dynamics in CdTe/CdSe type-Il quantum dots, Nanotechnology, 19 (2008) 115702

15. Y.F. Liu, J.S. Yu, In situ synthesis of highly luminescent glutathione-capped CdTe/ZnS quantum dots with biocompatibility, J. Colloid Interface Sci., 351 (2010) 1-9.

16. T. Toyoda, J. Sato, Q. Shen, Effect of sensitization by quantumsized CdS on photoacoustic and photoelectrochemical current spectra of porous $\mathrm{TiO}_{2}$ electrodes, Rev. Sci. Instrum., 74 (2003) 297-299.

17. Y.S. Lee, C.V.V.M. Gopi, M. Venkata-Haritha, H.J. Kim, Recombination control in high-performance quantum dot-sensitized solar cells with a novel $\mathrm{TiO}_{2} / \mathrm{ZnS} / \mathrm{CdS} / \mathrm{ZnS}$ heterostructure, Dalt. Trans., 45 (2016) 12917-12923.
18. J. Chen, W. Lei, W.Q. Deng, Reduced charge recombination in a co-sensitized quantum dot solar cell with two different sizes of CdSe quantum dot, Nanoscale, 3 (2011) 674-677.

19. Y.L. Lee, Y.S. Lo, Highly efficient quantum-dot-sensitized solar cell based on co-sensitization of CdS/CdSe, Adv. Funct. Mater., 19 (2009) 604-609.

20. X.Y. Yu, B.X. Lei, D. Bin Kuang, C.Y. Su, High performance and reduced charge recombination of $\mathrm{CdSe} / \mathrm{CdS}$ quantum dot-sensitized solar cells, J. Mater. Chem., 22 (2012) 1205812063 .

21. J. Liu, J. Liu, C. Wang, Z. Ge, D. Wang, L. Xia, L. Guo, N. Du, X. $\mathrm{Hao}, \mathrm{H}$. Xiao, A novel ZnS/SiO2 double passivation layers for the $\mathrm{CdS} / \mathrm{CdSe}$ quantum dots co-sensitized solar cells based on zinc titanium mixed metal oxides, Sol. Energy Mater. Sol. Cells, 208 (2020) 11038

22. T. Wang, A.M. Navarrete-López, S. Li, D.A. Dixon, J.L. Gole, Hydrolysis of $\mathrm{TiCl} 4$ : Initial Steps in the Production of $\mathrm{TiO}_{2}, \mathrm{~J}$. Phys. Chem. A, 114 (2010) 7561-7570.

23. H.J. Lee, J. Bang, J. Park, S. Kim, S.M. Park, Multilayered semiconductor ( $\mathrm{CdS} / \mathrm{CdSe} / \mathrm{ZnS}$ )-sensitized $\mathrm{TiO}_{2}$ mesoporous solar cells: All prepared by successive ionic layer adsorption and reaction processes, Chem. Mater., 22 (2010) 5636-5643.

24. X. Chen, J.L. Hutchison, P.J. Dobson, G. Wakefield, Highly luminescent monodisperse CdSe nanoparticles synthesized in aqueous solution, J. Mater. Sci., 44 (2009) 285-292.

25. D. Esparza, T. Lopez-Luke, J. Oliva, A. Cerdán-Pasarán, A. Martínez-Benítez, I. Mora-Seró, E.D. la Rosa, Enhancement of Eefficiency in quantum dot sensitized solar cells based on $\mathrm{CdS} / \mathrm{CdSe} / \mathrm{CdSeTe}$ heterostructure by improving the light absorption in the VIS-NIR region, Electrochim. Acta, 247 (2017) 899-909.

26. S.A. Pawar, D.S. Patil, H.R. Jung, J.Y. Park, S.S. Mali, C.K. Hong, J.C. Shin, P.S. Patil, J.H. Kim, Quantum dot sensitized solar cell based on $\mathrm{TiO} 2 / \mathrm{CdS} / \mathrm{CdSe} / \mathrm{ZnS}$ heterostructure, Electrochim. Acta, 203 (2016) 74-83.

27. J. Newman, K.E. Thomas-Alyea, Electrochemical Systems, 2004.

28. [28] W.W. Yu, L. Qu, W. Guo, X. Peng, Experimental determination of the extinction coefficient of CdTe, CdSe, and CdS nanocrystals, Chem. Mater., 15 (2003) 2854-2860.

29. S. Mussa Farkhani, A. Valizadeh, Review: three synthesis methods of $\mathrm{CdX}$ ( $\mathrm{X}=\mathrm{Se}, \mathrm{S}$ or Te) quantum dots., IET Nanobiotechnol., 8 (2014) 59-76.

30. M.A. Malik, P. O'Brien, N. Revaprasadu, A simple route to the synthesis of core/shell nanoparticles of chalcogenides, Chem. Mater., 14 (2002) 2004-2010.

31. E. Elibol, Effects of different counter electrodes on performance of CdSeTe alloy QDSSC, Sol. Energy., 197 (2020) 519-526.

32. J. Yang, X. Zhong, CdTe based quantum dot sensitized solar cells with efficiency exceeding $7 \%$ fabricated from quantum dots prepared in aqueous media, J. Mater. Chem. A, 4 (2016) 16553-16561.

33. C. Liu, L. Mu, J. Jia, X. Zhou, Y. Lin, Boosting the cell efficiency of CdSe quantum dot sensitized solar cellvia a modified ZnS post-treatment, Electrochim. Acta, 111 (2013) 179-184.

34. K. Zhao, Z. Pan, I. Mora-Seró, E. Cánovas, H. Wang, Y. Song, X. Gong, J. Wang, M. Bonn, J. Bisquert, X. Zhong, Boosting power conversion efficiencies of quantum-dot-sensitized solar cells beyond $8 \%$ by recombination control, J. Am. Chem. Soc., 137 (2015) 5602-5609. 